\title{
Classroom teaching in genetics and birth defects: the Nottingham experience
}

\author{
J S FITZSIMMONS \\ From the Clinical Genetic Service, City Hospital, Hucknall Road, Nottingham NG5 1PB.
}

SUMmaRY Advances in genetics and their implications for disease prevention make it important that there should be more emphasis on the teaching of human genetics in our schools. This is likely to require cooperation between educationalists and interested medical staff and two such ventures, one in North America and the other in Nottinghamshire, are described. The latter, involving school teachers, the Department of Health Education, and the staff of the Clinical Genetic Service appears to meet a need, and the teaching material developed is in use in secondary schools throughout the county. The teaching package contains simple examples of disease inheritance, brief information about antenatal diagnosis and genetic counselling, and some class exercises designed to encourage discussion on handicap and its effects on the family.

\section{The new genetics}

Recent developments in molecular biology and the emergence of the new genetics have important implications for medical services in the United Kingdom and elsewhere. Some aspects of these advances, particularly in relation to antenatal diagnosis, have created complex and often controversial social issues which may be highlighted further as research continues. In general, the community appears to be poorly informed about these new or, for that matter, earlier developments in genetics and there has been little public discussion about some of the consequent social and ethical issues. This is not a new problem and there has always been difficulty in ensuring the effective transmission of research knowledge to the community. The reasons for this are not clear, but society has a very important stake in many of the recent advances, and there should be more public awareness of their implications, particularly for disease prevention. This point was emphasised recently by Weatherall ${ }^{1}$ discussing the impact of the new genetics on clinical practice, and has been stressed by other writers over the past decade.

There have been no firm recommendations as to how best this can be achieved. The majority of the

Received for publication 16 January 1985

Accepted for publication 22 April 1985. public relies on the media, in particular television, for information about scientific advances. This can be very effective but the presentation of the material is not always at an appropriate level and may be over-dramatised and on occasions biased. ${ }^{2}$ Whatever their shortcomings, most television programmes dealing with scientific issues appear to be popular and this seems to reflect a genuine and widespread public interest in medical matters. It also indicates an increasing willingness by many people to play a more active role in the management of their own health problems. Helping patients to do this and to help themselves is not always easy but is becoming an important approach to dealing with various medical problems, including those due to genetic factors.

\section{Biology teaching in North America}

It is common experience that the majority of persons attending genetic counselling clinics have little or no knowledge of basic biological principles and may be completely unaware of the social consequences of recent advances. Many have difficulty in understanding even simple genetic facts and if they are to be helped to cope with the resultant ethical and social issues, they will need to have a greater understanding of the basic concepts of 
human genetics. This point was stressed by Hurd ${ }^{3}$ and others reviewing the situation in the USA, and they concluded that the majority of the adult public does not have an educational background in human biology. Those who have had teaching in biology at school may have little teaching in genetics and even less in human genetics, findings which apply equally to the United Kingdom. ${ }^{4}$ They concluded that in the long term greater public understanding will only be achieved by changes in the way genetics and biology are taught to the young people in our schools. A similar recommendation was made by Scriver $e t a l^{5}$ after enquiries which confirmed that high school students in Canada had little comprehension of the principles of human genetics and little or no awareness of their relevance to health related problems. Their survey of text books of biology revealed a lack of emphasis on human genetics and little or no attention to genetic disease. They further noted that teachers and pupils questioned were anxious to have improved teaching on the social effects of advances in these subjects. This provided the opportunity for some Canadian genetic services to cooperate with local schools in a new approach to teaching genetics and informing the pupils of the importance of the subject for society. For that reason, it was thought useful to review briefly the experience from North America, and to assess the possibility of cooperation with teachers in schools in a typical English Midlands county.

\section{Developments in USA: BSCS}

In 1975, the Biological Science Curriculum Study Group (BSCS), with financial support from the National Foundation-March of Dimes and the National Institutes of Health, conducted several studies into the state of education in human genetics in the United States and its role in the prevention of genetic disorders. As a consequence, there emerged the Center for Education in Human and Medical Genetics, part of the programme of the BSCS. This is now recognised by medical, scientific, educational, and governmental communities as qualified to coordinate the measures necessary to improve the teaching of genetics in schools and colleges. The project staff have over the years designed, developed, and evaluated several instructional books in human genetics for high school students. One of these, Genes and surroundings, considered suitable for students aged between 11 and 14 , provides an opportunity to gain experience of basic genetic principles in the context of human genetics. There is an accompanying teacher's guide and both this and the student's text represents a departure from the more traditional teaching approaches to the subject.
A second book, Basic genetics-a human approach, suitable for students aged 14 upwards, emphasises once again that the principles of genetics can be better illustrated in man than in other organisms. Neither text is meant to replace standard works on genetics and both should augment existing teaching material. The objectives of the course are impressive and are listed in table 1 . Table 2 lists the

TABLE 1 Aims of the BSCS course. These are ambitious but adequately covered in the texts supplied to teachers.

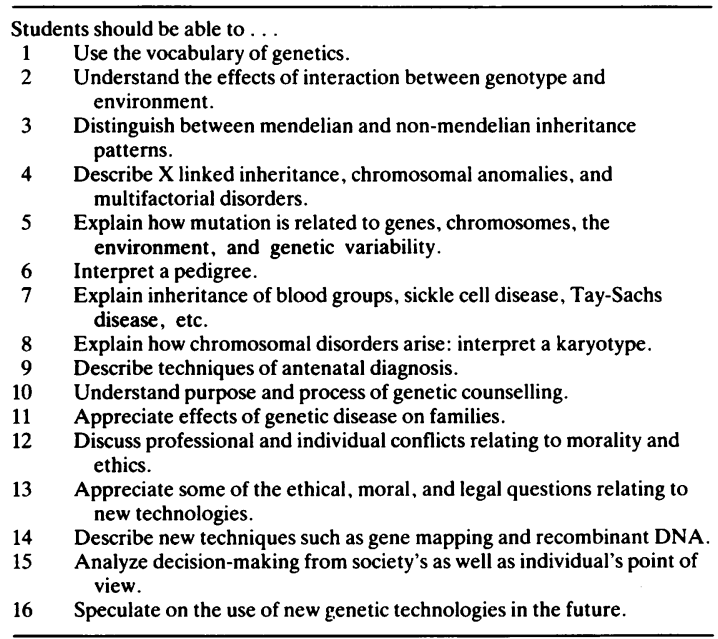

TABLE 2 Cystic fibrosis is chosen as an introductory activity over five classroom periods. The disease incidence, clinical features, family and social effects are all described. Probability concepts and personal decision making are also introduced.

\begin{tabular}{ll}
\hline Activity & $\begin{array}{l}\text { Minimum No of } \\
\text { class periods }\end{array}$ \\
\hline $\begin{array}{l}\text { Living with cystic fibrosis } \\
\text { Looking ahead } \\
\text { A new view of health: } \\
\text { genetics and environment }\end{array}$ & 5 \\
$\begin{array}{l}\text { Thinking about ethical questions } \\
\text { and case studies in genetics }\end{array}$ & 1 \\
$\begin{array}{l}\text { Robert Vandenberg wins } \\
\text { special Olympics }\end{array}$ & 3 \\
$\begin{array}{l}\text { Studying human chromosomes } \\
\quad \text { and countdown on chromosomes }\end{array}$ & 1 \\
$\begin{array}{l}\text { Reproductive technology: } \\
\text { today and tomorrow }\end{array}$ & $1-2$ \\
$\begin{array}{l}\text { Human variability } \\
\text { Is mutation rate higher in males } \\
\text { than in females? }\end{array}$ & $1-2$ \\
$\begin{array}{l}\text { Antenatal diagnosis } \\
\text { Genetic screening: } \\
\quad \text { prevention with problems }\end{array}$ & 2 \\
$\begin{array}{l}\text { Gene mapping } \\
\text { What is our responsibility to } \\
\text { future generations? }\end{array}$ & 2 \\
$\begin{array}{l}\text { Recessive genes and the gene pool } \\
\text { Selection and the gene pool } \\
\text { The miracle of spliced genes }\end{array}$ & $2-3$ \\
\hline
\end{tabular}


suggested activities for a six to seven week course from the second text. The standard throughout all texts is excellent with a well balanced mixture of factual knowledge, recommendations for subsequent exercises, and humour. The emphasis is always on relevance for both the individual and society. Each book runs to approximately 100 pages, is well illustrated, and the material attractively presented. They are available on request from the BSCS to colleges and schools throughout the United States.

\section{Projects in the UK}

\section{SCIENCE IN A SOCIAL CONTEXT}

There are clearly considerable financial implications in programmes such as the BSCS and nothing similar has yet appeared in the United Kingdom. There are various possible explanations for this, but it is encouraging to note the emergence of projects such as Science In a Social Context (SISCON), the Secondary Science Curriculum Review, and others over the past few years. These have been organised and developed by teachers who believe there is a need to emphasise different teaching strategies for our pupils. They want to encourage a more enquiring approach to science and to see less emphasis on the total body of knowledge gained. Teachers are asked to see themselves more as guides helping pupils to make reasoned personal decisions about problems than as possessors of the right answer. SISCON has produced a series of eight brief pamphlets for general studies at sixth form level. The course has been specifically designed to make scientific problems more accessible to the nonscientists as well as to explain the social aspects of science. One of these, Evolution and the human population, deals briefly with some of the moral, medical, and legal implications associated with handicapping conditions. It mentions, very briefly, genetic counselling and the practice of eugenics.

\section{SCIENCE CURRICULUM REVIEW}

The Secondary Science Curriculum Review is a five year programme of research initiated with the specific aim of reviewing and developing the science curriculum from the ages of 11 to 16 . This also recommends more emphasis on the importance of science for the individual and society. Both programmes are of obvious interest but there is, as yet, no report of their impact on the school curriculum or science teaching in secondary schools in this country. Many of these suggested changes have met with criticism and some biology teachers are concerned that there may be too much emphasis on the social aspects of biology and science in general. They want to see more stress being laid on teaching fundamental scientific principles. Such concern is understandable but there would seem to be no reason why these differing aims should not coexist. Many teachers in the United Kindom still see biology as a low status examination subject and as a consequence there are many able pupils leaving our schools with only very limited teaching in biology, and little or no teaching in genetics. This is a cause for concern and in view of the differing opinions on how science should be taught it is likely that any change in the curriculum at national level will be slow. This makes it important to look at how the situation might be improved at local level.

\section{Experience in Nottinghamshire}

Over the past few years, the Clinical Genetic Service and the Department of Health Education in Nottingham have examined possible ways to assist teachers prepared to introduce some of the changes similar to those pioneered by the BSCS. Initial enquiries confirmed that cooperation of this sort would be welcomed and during the autumn of $1981 \mathrm{a}$ short statement on genetics and birth defects was drafted and, after discussion, adapted to meet the teachers' requirements. In November 1982, the trial material was distributed to 20 schools in the county and city of Nottingham. These included comprehensive schools, sixth form colleges, and special schools for handicapped children. Those teachers willing to cooperate and to evaluate the information were from various backgrounds although most were biology graduates. None had previously used human disease to explain inheritance patterns and karyotypes had been only cursorily discussed. The majority welcomed the differing emphasis provided by introducing the relevance of genetics to health and to society. Their comments confirmed that the length of the book (approximately 42 pages) and its contents were satisfactory and required little alteration. The Nottingham Health Education Department undertook to bear the cost of publication and, in January 1984, 131 copies of the booklet were distributed to every secondary and further education establishment in Nottinghamshire. At the same time, teachers were invited to seminars to discuss the information and two of these were held in the spring of 1984. After this, questionnaires were circulated to all recipients of the book and their further comments requested and noted. No major alteration appeared to be necessary and the popularity of the material appeared to be confirmed by a need for a second printing. Classroom exercises were chosen to illustrate the various sections in the text and these are shown in table 3 . Some common 
TABLE 3 Classroom discussion topics designed to illustrate basic concepts discussed in the text. These include the aetiology of birth defects; single gene, chromosomal, and multifactorial inheritance; individual and social effects of disease and personal decision making; genetic counselling and antenatal diagnosis.

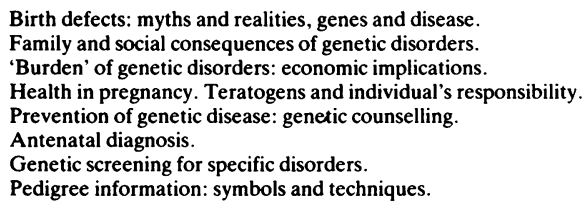

diseases, for example, cystic fibrosis, are dealt with in more detail and the opportunity was taken to introduce some basic facts relevant to conditions such as thalassaemia and sickle cell disease. Nottinghamshire, like other Midlands counties, has a considerable proportion of Asian and West African immigrants and it was considered important to make reference to screening for these two common problems. ${ }^{6}$ Rapid developments in molecular genetics and recombinant DNA technology make it essential to include some information on these in subsequent revisions.

From the written and verbal comments received, the material has been welcomed, is apparently not available elsewhere, and seems to be useful. A formal evaluation of the effectiveness of the information on student knowledge or attitudes has not yet been attempted but initial reaction has been very encouraging. A recent evaluation of the BSCS teaching programme ${ }^{7}$ in the USA concluded that this type of presentation of biology was more favourably received by students than traditional biology teaching methods. A further finding was that a general science background made no difference to the performance score in the BSCS biology course.

The exact place for this sort of material in the school curriculum has not yet been finally decided. Biology teachers in general felt that it was best included in standard biology teaching on genetics. This subject is unfortunately only taught to the more able pupils and this could restrict its use considerably. Some thought it should be part of the teaching in courses such as social biology or preparation for parenthood. A few considered it useful as a discussion document in classes on religious education. None of the teachers felt that the material was unsuitable because of its ethical or moral implications and they were asked specifically about this. Some felt it was unsuitable because of the educational attainment of their pupils, but the majority thought it added an approach to biology which was much needed.

Weatherall, ${ }^{1}$ in his monograph, concluded that the only certainty in the field of molecular biology is that molecular biology will not wait for us. Developments in genetics will continue to have important implications for the nation's health and the public needs to be made aware of their potential. How best this should be done needs further discussion but in the long term it is likely to be most effectively ensured by changes in biology and genetics teaching in our schools. ${ }^{8}$ The aims of this cooperative teaching effort in Nottinghamshire were to increase young people's awareness of genetics, its relevance to health matters, and to disease prevention. It was also hoped that it might encourage a more tolerant attitude to handicap in children and adults, and would serve as an introduction to ethics and informed personal decision making. The effectiveness of the project clearly needs further assessment, but there is evidence that more teachers would welcome this sort of initiative and Clinical Genetic Services need to become more involved. ${ }^{9}$

I would like to thank Mr Ian McCafferty, Area Health Education Officer, Miss Hazel Daniels, and Mr G C Doyle, Department of Health Education, Huntingdon House, Nottingham, for their cooperation with this project. I am also very grateful to Joseph D McInerney, Associate Director of the BSCS, The Colorado College, Colorado Springs, Colorado, USA for his very helpful correspondence and encouragement over the past few years. I would also like to thank the BSCS for permission to reproduce some of the objectives of their course in tables 1 and 2. I am grateful to Dr S Bundey for helpful criticism and Miss P C Webster for typing the manuscript.

Copies of the Nottingham booklet are available on request to the author.

\footnotetext{
References

1 Weatherall DJ. The new genetics and clinical practice. London Nuffield Provincial Hospitals Trust, 1982:126.

${ }^{2}$ Glover J. Genetic engineering. The Listener 1982;18 November:5-6.

${ }^{3}$ Hurd PD. The historical/philosophical background of education in human genetics in the United States. Biol Sci Curr Study J 1978;1:3-8.

${ }^{4}$ Fitzsimmons JS. The teaching of human genetics in schools J Med Genet 1983;20:244-8.

${ }^{5}$ Scriver CR, Scriver DE, Clow CL, et al. The education of citizens: human genetics. Am Biol Teach, May 1978:280-4.

${ }^{6}$ Modell B. Social implications of fetal diagnosis. Prenatal diagnosis. Proceedings of the Eleventh Study Group of the Royal College of Obstetricians and Gynaecologists, September 1983:385.
} 
${ }^{7}$ Shymansky J. BSCS programs: just how effective are they? Am Biol Teach, January 1984;46:54-7.

${ }^{8}$ Fitzsimmons JS. The need for more human genetics in biology and health education. School Science Review, December 1983:368-73.

${ }^{9}$ Fletcher JC, Berg K, Tranoy KE. Ethical aspects of medical genetics: a proposal for guidelines in genetic counselling, prenatal diagnosis and screening. Clin Genet 1985;27:199-205.

Correspondence and requests for reprints to Dr J S Fitzsimmons, Clinical Genetic Service, City Hospital, Hucknall Road, Nottingham NG5 1PB. 